\title{
Testing Weak Form of Market Efficiency in Nepal Jeetendra Dangol, Ph.D*
}

\begin{abstract}
The paper investigates the weak form of market efficiency for overall and sectorial indices. The Nepalese stock returns are found not being normally distributed during the study period. The autocorrelation of the stock returns was reduced by correcting the data with the application of the methodology suggested by Miller et al. (1994). The Nepalese stock market has suffered from the problem of thin-trading. Overall, the Nepalese market is not weak-form efficient on the basis of the analysis performed by employing observed returns series; but it is found a weak-form efficient in case of the analysis while using corrected data after adjusting infrequent trading. Hence, the study is supported to the random-walk and weak form of market efficiency.
\end{abstract}

Key words: Market efficiency, Random-walk, Serial correlation

*Associate professor and Deputy Director at School of Management, Tribhuvan University, Nepal, Email: jdangol@gmail.com 


\section{Introduction}

According to Fama (1970, 1991), the Efficient Market Hypothesis (EMH) suggests that gaining from predicting price movements is very difficult and unlikely. The main factor behind the price changes is the arrival of new information. A market is said to be "efficient" if price adjusts quickly, and, on average, without bias, to new information. As a result, the current prices of securities reflect all available information at any given point in time.

One of the major premises of efficient market theory is that the market quickly impounds any publicly available information, including macroeconomic information that might be used to predict stock prices. The term efficiency is used to describe a market in which relevant information is impounded into the price of financial assets. In general terms, the theory of efficient markets is concerned with stock prices at any point in time fully reflect available information (Fama, 1970).

The Fama (1970) classifies the market efficiency into Weak form efficiency, Semi-strong form efficiency and Strong form efficiency. After twenty years of market efficiency literature published in 1970, Fama (1991) proposed to change the categories of market efficiency, namely: (1) Using tests for return predictability instead of weak-form tests, (2) Using event studies instead of semistrong-form tests and (3) Using test for private information instead of strong-form tests.

\section{Literature Review}

Fama and French (1988), Lo and MacKinlay (1988), and Jegadeesh (1990) showed the predictability of future returns and concluded that the market was inefficient in weak form. However, Jarrett and Kyper (2005) provided the evidence that the stock markets of United States show characteristics of a random-walk and, thus, were efficient in the weak form. Similarly, Narayan and Prasad (2007) evaluated market efficiency of the seventeen European countries and reported the results were consistent with the efficient market hypothesis.

The findings of market efficiency tests - mostly weak form efficiency tests - on emerging markets were rather varied. Alam, Hasan and Kadapakham (1999); and Cheung and Coutts (2001) studies found evidences in favour of weak form efficiency. On the contrary, studies of 
Lee, Chen, \& Rui (2001); Smith, Jefferies and Ryoo (2002); and Mobarek and Keasey (2002) found evidences of predictability of stock prices.

Alam et al. (1999) and Mobarek and Keasey (2002) have tested the market efficiency of the Bangladesh with the conflicting results. Applying a variance ratio test, Alam et al. (1999) have discovered that the monthly stock price index series followed a random-walk. This implies the existence of weak-form efficiency. However, by applying runs and autocorrelation tests, Mobarek and Keasey (2002) concluded that the daily price index series did not follow a randomwalk. In the context of India, Ahmad, Ashraf and Ahmed (2006) examined the weak form efficient market hypothesis using the daily data in India. The study reported that the stock exchanges have rejected random-walk hypothesis. Similarly, Gupta and Basu (2007) as well as Siddiqui and Gupta (2009) also rejected the weak form of market efficiency in India. In light of the above studies, a need for testing the level of market efficiency in the Nepalese stock market has been felt.

In the context of Nepal, using autocorrelation and runs tests, Pradhan and Upadhyay (2006), Bhatta (2008), Bhatta (2010) and Dangol (2010a) found that the Nepalese stock market did not follow random-walk hypothesis and was inefficient in weak form for daily, weekly and monthly market returns series. Similarly, Dangol (2010b) examined random-walk behaviour on daily market returns of the Nepal Stock Exchange (NEPSE) using Augmented Dickey-Fuller (ADF) and Phillips-Perron (PP) unit root tests for the period between July 14, 2000 and January 14, 2010. The study found that the Nepalese stock market did not show characteristics of randomwalk and thus, it was not efficient in the weak form. It implicates that market participants have opportunities to predict future price and earn abnormal returns from the Nepalese stock market. The finding of the Nepalese stock market being inefficient in the weak form has also been reported in the study of Dangol (2012). Shrestha (2001) also highlighted the Nepalese stock market as inefficient.

Dangol (2011) examined the random-walk behaviour and weak form of market efficiency in the Nepalese and Indian stock markets employing variance ratio and run tests as methodologies for the period between July 1, 2003 and June 30, 2010. The study found that the variance-ratio tests 
were rejected the random-walk hypothesis for both countries' stock markets. There was no evidence for weak form efficiency in the return series of the Nepalese stock market. However, the study showed the Indian stock markets efficient in the weak-form. It implies that market participants have opportunities to predict future prices and earn abnormal returns in the Nepalese stock market, while the development of trading strategies might not be able to earn excess returns in the Indian stock markets. Furthermore, mean-reverting process was found in both the Nepalese and Indian stock markets, suggesting overinflated stock prices, abnormally high volatility and frequent market correction from a bubble effect.

In conclusion, the studies on weak form of market efficiency reveal that the stock prices are randomly formulated in a majority of the developed stock markets. But few emerging markets have also shown characteristics of random-walk behaviour, whereas, the emerging markets including South-Asian region are inefficient in the weak form. The reasons for inefficiencies are largely due to autocorrelation structures in their returns series. The developed markets show autocorrelation on its returns series, probably because of systematic changes in expected stock returns or rational behaviour of the investors. On the other hand, the majority of the emerging equity markets provide positive autocorrelation that indicates unusual rapid economic growth.

As such, in the context of Nepal, there is the need for evaluating the level of market efficiency. Thus, the main objective of the study is to test weak form of market efficiency.

\section{Research methods}

\subsection{Testable hypotheses}

The following null hypotheses were formulated:

\section{Hypothesis 1: Distribution patterns of stock prices}

Null hypothesis, $\mathrm{H}_{0}$ : "Stock returns series in the NEPSE follow a normal distribution".

\section{Hypothesis 2: Serial correlation in stock returns}

Null hypothesis, $\mathrm{H}_{0}$ : “There is no serial correlation between the stock returns". 


\subsection{Data}

The study employs daily and weekly returns of value-weighted portfolios of stocks listed with the Nepal stock exchange (NEPSE) for the period of ten years between Mid-July 2000 and MidJuly 2010.

The natural log of the relative price has been computed for the daily/weekly intervals to produce a time series of continuously compounded returns, such that:

$$
R_{t}=\operatorname{Ln}\left(\frac{P_{t}}{P_{t-1}}\right) \times 100
$$

where $\mathrm{P}_{\mathrm{t}}$ and $\mathrm{P}_{\mathrm{t}-1}$ represent the stock index price or individual security closing price at time $t$ and t-1 and Ln refers to natural log. The reasons to take logarithm returns are justified by both theoretically and empirically. Theoretically, logarithmic returns are analytically more tractable when linking returns over longer intervals. Empirically, logarithmic returns are more likely to be normally distributed, which is a prior condition of standard statistical techniques (Strong, 1992).

\subsection{Estimating the true index-correcting for infrequent trading}

In investigating the pattern of sole equity market of Nepal, it is important to take its characteristics like thin-trading into consideration. To separate the effect of thin trading, the study has applied corrections to the observed index by using a methodology proposed by Miller, Muthuswamy and Whaley (1994). To correct for infrequent trading, this methodology basically suggests a moving average model (MA) to remove the impact of thin trading, as the MA reflects the number of non-trading days and calculates returns adjusted for the effect of non-trading days. However, given the difficulties in identifying the non-trading days, Miller et al. (1994) have shown that it is equivalent to estimate an auto-regressive or AR (1) model from which the nontrading adjustment can be obtained. Specifically, this model estimated the following specifications related to the returns, $\mathrm{R}$ at time $\mathrm{t}$ :

$$
\mathrm{R}_{\mathrm{t}}=\alpha_{1}+\alpha_{2} \mathrm{R}_{\mathrm{t}-1}+\varepsilon_{\mathrm{t}}
$$




$$
\mathrm{R}_{\mathrm{t}}^{\mathrm{adj}}=\frac{\varepsilon_{\mathrm{t}}}{\left(1-\alpha_{2}\right)}
$$

where $\mathrm{R}_{\mathrm{t}}^{\text {adj }}$ is the return at time $\mathrm{t}$ adjusted for thin-trading. Miller et al. (1994) find thin trading adjustment reduces the negative correlation among returns. The model above assumes that nontrading adjustment is constant over time.

\subsection{Methodology to test hypothesis 1: Distribution patterns of the stock prices}

To assess the distribution patterns of the stock returns, the study has employed normality tests. First it has determined whether the stock returns follow a normal distribution or not. If stock returns series follow a normal distribution, it belongs to the assumption of the random walk model; hence the market accepts the weak form of efficiency. The current study has performed normality tests using the skewness, kurtosis and Jarque-Bera statistic.

\subsection{Methodology to test hypothesis 2: Serial correlation in stock returns series}

Autocorrelation test is a reliable measure for testing of either dependence of random variables in a series. The ACF, $I_{k}$, is used to determine the independence of the stock price changes. This measures the amount of linear dependence between observations in a time series that are separated by lag $\mathrm{k}$, and is computed as under:

$$
I_{k}=\frac{\sum_{t=1}^{n-k}\left(R_{m t}-\overline{R_{m t}}\right)\left(R_{m t+k}-\overline{R_{m t}}\right)}{\sum_{t=1}^{n}\left(R_{m t}-\overline{R_{m t}}\right)^{2}}
$$

where $I_{k}$ is the autocorrelation coefficient for a lag of $k$ time units and $n$ is the number of observations. If the price changes of the stocks are independently distributed, $\mathrm{I}_{\mathrm{k}}$ will be zero for all time lags. The study has considered only the first lag.

\section{Empirical test results}

\subsection{Test results of the hypothesis 1: Distribution patterns of the stock prices}

To test the weak form of market efficiency, the study has first determined whether the stock returns follow a normal distribution or not. If stock returns series follow a normal distribution, it 
belongs to the assumption of random-walk model; hence it is accepted as the weak form of market efficiency. The study tests normality using the skewness, kurtosis and Jarque-Bera statistic.

Descriptive statistics can be interpreted to test the informational efficiency of the stock market. Generally, values for zero skewness and kurtosis at three represent that the observed distribution is normally distributed. Table 1 and Table 2 show the descriptive statistics of daily and weekly returns of overall NEPSE index and other nine sectoral indices, i.e., commercial banking, development banking, finance, insurance, hydropower, hotel, trading, manufacturing and others. The distribution of daily observed (raw data) stock returns have slightly negative-skewed in the cases of overall index, commercial bank index, development bank index, finance sector index and manufacturing index but it is highly leptokurtic (peaked) in all indices. Similarly, in the case of weekly returns, overall index and commercial banking index are positively-skewed, which is negative-skewed in case of daily returns series, however. The 'other' sector indices of the weekly returns are similar to the results of daily returns and it is highly leptokurtic (peaked) in all indices.

Descriptive statistics of daily and weekly returns with correct data have been presented in Table 3 and 4. These tables also provide evidences of highly leptokurtic distributions in all returns indices and positive-skewed (overall index, hydro, hotel, trading, others) and negative-skewed (development banking, finance, insurance, manufacturing) in overall study period. Therefore, the skewed and leptokurtic frequency distribution of daily and weekly market returns series indicate that the distributions are not normal. Jarque-Bera test also rejects the null hypothesis of normal distribution for all indices. It gives evidence that the frequency distribution is not normal for daily, weekly, daily corrected and weekly corrected returns to all indices during the study period. Thus, the null hypothesis of non-normal distribution of return series is accepted.

All returns series show the positive mean return except for finance, insurance, hotel and trading sectors of weekly corrected data in the total study period. Similarly, the recent period of study (July 17, 2005 - July 15, 2010) reports excess positive mean returns than previous period (July 17, 2000 - July 16, 2005). It is an indicator of economic growth and continuation development 
of the Nepalese stock market. The market has positive mean returns with low variance; it indicates that the Nepalese stock market involves low risk. This may have happened due to market size, technology, information and attitude of investors towards the risk.

\subsection{Test results of the hypothesis 2: Serial correlation in stock returns series}

The serial correlation coefficient test is a widely employed procedure that tests the relationship between returns in the current period and those in the previous period. If there is no significant autocorrelation found, then the series are assumed to follow a random-walk. Table 5 and 6 report the statistics and p-values for the tests of serial independence, namely, the parametric serial correlation coefficient for daily and weekly return series. In the case of daily observed return series, alternative hypotheses of serial correlation for all indices except commercial banking, development banking, hotel and trading sectors are accepted at the .05 level or higher in the overall study periods. But, in cases of sub-periods, the all indices accepted the alternative hypothesis of serial correlation at the .05 level or higher.

Similarly, in the case of weekly return series, the alternative hypothesis of serial correlation for all indices except commercial banking, hydropower, hotel, trading and other sectors are accepted at the .05 level or higher in the total study periods. The similar results are reported in the subperiods as well. The significance of the autocorrelation coefficient indicates that the market is not efficient in the weak form.

Table 7 and Table 8 depict the serial correlation coefficient and p-values for daily and weekly corrected return series. In daily return series, the alternative hypothesis of serial correlation for all indices except manufacturing sector is rejected at the .05 level or higher in the overall study periods. But in case all indices of weekly corrected return series, the alternative hypothesis of serial correlation is rejected at the .05 level. The similar results are reported in the sub-periods as well. It provides the evidence that corrected return series reduces the autocorrelation. The result is consistent with Miller et al. (1994) who found that thin trading adjustment reduces the negative correlation among returns. Thus, the Nepalese stock market has suffered from the problem of thin trading. 
Table 1: Descriptive statistics of daily stock returns (Observed data)

The table represents descriptive statistics and the tests of normality for daily stock returns on the observed data (raw data) of Nepal Stock Exchange (NEPSE). Descriptive statistics include mean, median maximum, minimum and standard deviation. Normality tests statistics include Skewness, Kurtosis and Jarque-Bera tests. Estimates are given for overall market returns series as well as for nine other sectors returns series for full sample study period from July 17, 2000 to July 15, 2010 and the two sub-periods.

\begin{tabular}{|c|c|c|c|c|c|c|c|c|c|c|}
\hline Indices & Observations & Mean & Median & Maximum & Minimum & Std. Dev. & Skewness & Kurtosis & Jarque-Bera & Probability \\
\hline \multicolumn{11}{|c|}{ Panel A: 2000 July 17 - 2010 July 15} \\
\hline Overall & 2334 & 0.012 & 0.010 & 37.876 & -38.153 & 1.635 & -0.116 & 254.200 & 6136613.00 & 0.000 \\
\hline Commercial Banking & 2334 & 0.006 & 0.008 & 22.513 & -24.163 & 1.968 & -0.109 & 33.466 & 90272.54 & 0.000 \\
\hline Development Banking & 1981 & 0.025 & 0.000 & 54.397 & -54.300 & 2.318 & -1.324 & 322.605 & 8431972.00 & 0.000 \\
\hline Finance & 2334 & 0.011 & 0.009 & 48.677 & -48.267 & 2.134 & -0.368 & 296.769 & 8392771.00 & 0.000 \\
\hline Insurance & 2334 & 0.025 & 0.000 & 54.043 & -53.746 & 1.812 & 0.161 & 673.695 & 43746200.00 & 0.000 \\
\hline Hydropower & 696 & 0.008 & -0.045 & 8.748 & -6.795 & 1.670 & 0.676 & 6.698 & 449.61 & 0.000 \\
\hline Hotel & 2334 & 0.006 & 0.000 & 29.535 & -11.550 & 1.039 & 8.765 & 303.129 & 8789881.00 & 0.000 \\
\hline Trading & 2334 & 0.035 & 0.000 & 40.841 & -9.368 & 1.197 & 16.793 & 589.854 & 33602310.00 & 0.000 \\
\hline Manufacturing & 2334 & 0.010 & 0.000 & 32.835 & -32.835 & 1.799 & -0.305 & 217.413 & 4470913.00 & 0.000 \\
\hline Other & 2334 & 0.024 & 0.000 & 104.314 & -67.200 & 3.631 & 11.033 & 405.576 & 15808422.000 & 0.000 \\
\hline \multicolumn{11}{|c|}{ Panel B: 2000 July 17 - 2005 July 16} \\
\hline Overall & 1188 & -0.019 & 0.005 & 37.876 & -38.153 & 1.898 & -0.122 & 273.727 & 3628005.00 & 0.000 \\
\hline Commercial Banking & 1188 & -0.021 & 0.007 & 22.513 & -24.163 & 2.145 & -0.067 & 43.436 & 80937.54 & 0.000 \\
\hline Development Banking & 835 & -0.025 & 0.000 & 54.397 & -54.300 & 2.868 & -0.604 & 315.014 & 3387124.00 & 0.000 \\
\hline Finance & 1188 & -0.025 & -0.005 & 48.677 & -48.267 & 2.232 & 0.188 & 378.400 & 6975806.00 & 0.000 \\
\hline Insurance & 1188 & 0.004 & 0.000 & 54.043 & -53.746 & 2.386 & 0.137 & 440.178 & 9460677.00 & 0.000 \\
\hline Hydropower & N.A. & & & & & & & & & \\
\hline Hotel & 1188 & -0.056 & 0.000 & 9.957 & -11.550 & 1.052 & -1.657 & 40.197 & 69032.60 & 0.000 \\
\hline Trading & 1188 & 0.000 & 0.000 & 8.486 & -9.368 & 0.803 & -1.510 & 52.733 & 122884.20 & 0.000 \\
\hline Manufacturing & 1188 & -0.018 & 0.000 & 31.116 & -31.116 & 1.973 & -0.396 & 160.101 & 1221730.00 & 0.000 \\
\hline Other & 1188 & 0.010 & 0.000 & 104.314 & -20.630 & 3.741 & 19.146 & 524.010 & 13509433.00 & 0.000 \\
\hline \multicolumn{11}{|c|}{ Panel C: 2005 July $17-2010$ July 15} \\
\hline Overall & 1146 & 0.045 & 0.018 & 5.470 & -7.228 & 1.307 & 0.007 & 5.879 & 395.77 & 0.000 \\
\hline Commercial Banking & 1146 & 0.035 & 0.012 & 7.720 & -10.818 & 1.766 & -0.158 & 7.122 & 815.91 & 0.000 \\
\hline Development Banking & 1146 & 0.061 & 0.000 & 13.011 & -27.530 & 1.817 & -2.939 & 55.403 & 132776.40 & 0.000 \\
\hline Finance & 1146 & 0.048 & 0.043 & 34.058 & -33.546 & 2.028 & -1.121 & 166.585 & 1278026.00 & 0.000 \\
\hline Insurance & 1146 & 0.047 & 0.000 & 7.841 & -7.040 & 0.887 & 0.498 & 18.611 & 11683.82 & 0.000 \\
\hline Hydropower & 696 & 0.008 & -0.045 & 8.748 & -6.795 & 1.670 & 0.676 & 6.698 & 449.61 & 0.000 \\
\hline Hotel & 1146 & 0.071 & 0.000 & 29.535 & -6.946 & 1.021 & 20.685 & 608.649 & 17596936.00 & 0.000 \\
\hline Trading & 1146 & 0.072 & 0.000 & 40.841 & -8.627 & 1.499 & 17.607 & 482.316 & 11029475.00 & 0.000 \\
\hline Manufacturing & 1146 & 0.038 & 0.000 & 32.835 & -32.835 & 1.600 & -0.088 & 325.106 & 4954177.00 & 0.000 \\
\hline Other & 1146 & 0.039 & 0.000 & 67.200 & -67.200 & 3.514 & 0.854 & 244.623 & 2787855.00 & 0.000 \\
\hline
\end{tabular}


Table 2: Descriptive statistics of weekly stock returns (Observed data)

The table represents descriptive statistics and the tests of normality for weekly stock returns on the observed data (raw data) of Nepal Stock Exchange (NEPSE). Descriptive statistics include mean, median maximum, minimum and standard deviation. Normality tests statistics include Skewness, Kurtosi s and Jarque-Bera tests. Estimates are given for overall market returns series as well as for nine other sectors returns series for full sample study period from July 17, 2000 to July 15, 2010 and the two sub-periods.

\begin{tabular}{|c|c|c|c|c|c|c|c|c|c|c|}
\hline Indices & Observations & Mean & Median & Maximum & Minimum & Std. Dev. & Skewness & Kurtosis & Jarque-Bera & Probability \\
\hline \multicolumn{11}{|c|}{ Panel A: 2000 July 17 - 2010 July 15} \\
\hline Overall & 512 & 0.056 & -0.039 & 11.861 & -9.910 & 3.018 & 0.207 & 4.695 & 64.925 & 0.000 \\
\hline Commercial Banking & 512 & 0.030 & 0.063 & 21.158 & -16.325 & 4.234 & 0.084 & 5.803 & 168.246 & 0.000 \\
\hline Development Banking & 434 & 0.112 & 0.000 & 23.628 & -31.414 & 4.061 & -0.358 & 18.097 & 4130.971 & 0.000 \\
\hline Finance & 512 & 0.051 & -0.020 & 10.408 & -18.147 & 2.304 & -0.400 & 16.048 & 3645.878 & 0.000 \\
\hline Insurance & 512 & 0.114 & 0.000 & 9.959 & -9.839 & 2.139 & 0.509 & 9.492 & 921.299 & 0.000 \\
\hline Hydropower & 153 & 0.034 & -0.431 & 18.639 & -12.619 & 4.432 & 0.925 & 5.889 & 75.011 & 0.000 \\
\hline Hotel & 512 & 0.028 & 0.000 & 35.825 & -13.767 & 2.491 & 5.207 & 89.344 & 161360.200 & 0.000 \\
\hline Trading & 512 & 0.161 & 0.000 & 42.378 & -15.772 & 2.773 & 6.711 & 110.841 & 251943.100 & 0.000 \\
\hline Manufacturing & 512 & 0.045 & 0.000 & 27.863 & -24.853 & 2.297 & 0.439 & 77.431 & 118204.100 & 0.000 \\
\hline Other & 512 & 0.109 & 0.000 & 105.627 & -21.095 & 7.167 & 8.321 & 111.430 & 256727.100 & 0.000 \\
\hline \multicolumn{11}{|c|}{ Panel B: 2000 July 17 - 2005 July 16} \\
\hline Overall & 258 & -0.086 & -0.103 & 11.861 & -9.706 & 2.712 & 0.412 & 6.442 & 134.676 & 0.000 \\
\hline Commercial Banking & 258 & -0.098 & -0.065 & 21.158 & -16.325 & 4.219 & 0.290 & 7.439 & 215.426 & 0.000 \\
\hline Development Banking & 180 & -0.118 & 0.000 & 5.529 & -23.453 & 2.295 & -5.772 & 60.900 & 26142.630 & 0.000 \\
\hline Finance & 258 & -0.113 & -0.159 & 9.837 & -8.456 & 1.520 & 0.265 & 14.191 & 1349.350 & 0.000 \\
\hline Insurance & 258 & 0.018 & -0.037 & 9.837 & -8.456 & 1.816 & 0.397 & 10.835 & 666.654 & 0.000 \\
\hline Hydropower & N.A. & & & & & & & & & \\
\hline Hotel & 258 & -0.258 & 0.000 & 9.999 & -13.767 & 2.374 & -1.020 & 12.112 & 937.352 & 0.000 \\
\hline Trading & 258 & -0.002 & 0.000 & 8.486 & -9.790 & 1.790 & -0.880 & 14.079 & 1352.703 & 0.000 \\
\hline Manufacturing & 258 & -0.081 & 0.000 & 27.863 & -24.853 & 3.000 & 0.446 & 52.712 & 26575.100 & 0.000 \\
\hline Other & 258 & 0.045 & 0.000 & 105.627 & -20.630 & 8.427 & 8.698 & 103.994 & 112901.600 & 0.000 \\
\hline \multicolumn{11}{|c|}{ Panel C: 2005 July 17 - 2010 July 15} \\
\hline Overall & 254 & 0.201 & 0.252 & 10.116 & -9.910 & 3.299 & 0.046 & 3.678 & 4.957 & 0.084 \\
\hline Commercial Banking & 254 & 0.160 & 0.255 & 12.926 & -15.631 & 4.254 & -0.122 & 4.256 & 17.315 & 0.000 \\
\hline Development Banking & 254 & 0.275 & 0.000 & 23.628 & -31.414 & 4.944 & -0.010 & 12.051 & 866.941 & 0.000 \\
\hline Finance & 254 & 0.218 & 0.180 & 10.408 & -18.147 & 2.884 & -0.577 & 12.229 & 915.521 & 0.000 \\
\hline Insurance & 254 & 0.212 & 0.019 & 9.959 & -9.839 & 2.423 & 0.484 & 8.124 & 287.782 & 0.000 \\
\hline Hydropower & 153 & 0.034 & -0.431 & 18.639 & -12.619 & 4.432 & 0.925 & 5.889 & 75.011 & 0.000 \\
\hline Hotel & 254 & 0.319 & 0.000 & 35.825 & -7.260 & 2.576 & 10.270 & 143.918 & 214626.700 & 0.000 \\
\hline Trading & 254 & 0.326 & 0.000 & 42.378 & -15.772 & 3.497 & 6.785 & 86.464 & 75675.390 & 0.000 \\
\hline Manufacturing & 254 & 0.172 & 0.000 & 6.551 & -5.660 & 1.217 & 0.773 & 13.127 & 1110.632 & 0.000 \\
\hline Other & 254 & 0.174 & 0.000 & 62.638 & -21.095 & 5.622 & 5.144 & 63.446 & 39788.100 & 0.000 \\
\hline
\end{tabular}


Table 3: Descriptive statistics of daily stock returns (Corrected data)

The table represents descriptive statistics and the tests of normality for daily stock returns on the corrected data of Nepal Stock Exchange (NEPSE). Descriptive statistics include mean, median maximum, minimum and standard deviation. Normality tests statistics include Skewness, Kurtosis and Jarque-Bera tests. Estimates are given for overall market returns series as well as for nine other sectors returns series for full sample study period from July 17, 2000 to July 15, 2010 and the two sub-periods.

\begin{tabular}{|c|c|c|c|c|c|c|c|c|c|c|}
\hline Indices & Observations & Mean & Median & Maximum & Minimum & Std. Dev. & Skewness & Kurtosis & Jarque-Bera & Probability \\
\hline \multicolumn{11}{|c|}{ Panel A: 2000 July 17 - 2010 July 15} \\
\hline Overall & 2333 & 0.001 & -0.012 & 35.194 & -32.583 & 1.510 & 1.164 & 222.854 & 4699173.000 & 0.000 \\
\hline Commercial Banking & 2333 & 0.002 & 0.006 & 23.084 & -24.464 & 1.992 & -0.092 & 34.138 & 94253.460 & 0.000 \\
\hline Development Banking & 1980 & 0.000 & -0.025 & 37.477 & -45.908 & 1.925 & -4.475 & 255.565 & 5269211.000 & 0.000 \\
\hline Finance & 2333 & 0.000 & -0.004 & 24.275 & -34.474 & 1.393 & -3.166 & 246.249 & 5755722.000 & 0.000 \\
\hline Insurance & 2333 & 0.007 & -0.035 & 42.573 & -70.048 & 2.293 & -5.926 & 488.087 & 22887689.000 & 0.000 \\
\hline Hydropower & 695 & 0.015 & -0.041 & 10.668 & -8.879 & 2.262 & 0.408 & 5.724 & 234.214 & 0.000 \\
\hline Hotel & 2333 & 0.000 & -0.006 & 29.681 & -11.651 & 1.044 & 8.758 & 303.127 & 8785965.000 & 0.000 \\
\hline Trading & 2333 & 0.000 & -0.035 & 42.154 & -9.716 & 1.236 & 16.785 & 590.041 & 33609249.000 & 0.000 \\
\hline Manufacturing & 2333 & 0.000 & -0.010 & 23.732 & -25.064 & 1.305 & -0.944 & 183.312 & 3160820.000 & 0.000 \\
\hline Other & 2333 & 0.000 & -0.024 & 96.188 & -61.938 & 3.333 & 10.584 & 397.588 & 15178894.000 & 0.000 \\
\hline \multicolumn{11}{|c|}{ Panel B: 2000 July 17 - 2005 July 16} \\
\hline Overall & 1187 & 0.000 & 0.014 & 30.206 & -22.066 & 1.443 & 4.654 & 212.139 & 2167550.000 & 0.000 \\
\hline Commercial Banking & 1187 & 0.001 & 0.017 & 15.958 & -20.768 & 1.819 & -0.375 & 35.724 & 52991.260 & 0.000 \\
\hline Development Banking & 834 & 0.000 & 0.025 & 22.243 & -38.243 & 1.833 & -8.873 & 269.677 & 2482253.000 & 0.000 \\
\hline Finance & 1187 & 0.000 & 0.009 & 17.546 & -32.790 & 1.334 & -9.129 & 351.168 & 6011860.000 & 0.000 \\
\hline Insurance & 1187 & 0.000 & -0.004 & 20.055 & -36.839 & 1.451 & -10.250 & 398.114 & 7741978.000 & 0.000 \\
\hline Hydropower & N.A. & & & & & & & & & \\
\hline Hotel & 1187 & 0.000 & 0.056 & 9.185 & -10.264 & 0.979 & -1.538 & 38.170 & 61645.650 & 0.000 \\
\hline Trading & 1187 & 0.000 & 0.000 & 7.721 & -8.522 & 0.727 & -1.259 & 50.241 & 110690.000 & 0.000 \\
\hline Manufacturing & 1187 & 0.000 & 0.018 & 25.383 & -20.243 & 1.567 & 1.315 & 140.166 & 930873.100 & 0.000 \\
\hline Other & 1187 & 0.000 & -0.010 & 110.556 & -21.891 & 3.963 & 19.167 & 525.466 & 13573361.000 & 0.000 \\
\hline \multicolumn{11}{|c|}{ Panel C: 2005 July 17 - 2010 July 15} \\
\hline Overall & 1146 & 0.004 & 0.003 & 8.464 & -11.574 & 1.846 & -0.094 & 7.481 & 960.261 & 0.000 \\
\hline Commercial Banking & 1146 & 0.005 & -0.002 & 12.247 & -15.551 & 2.357 & -0.203 & 8.704 & 1561.220 & 0.000 \\
\hline Development Banking & 1146 & 0.000 & -0.061 & 17.471 & -36.113 & 2.331 & -3.115 & 60.118 & 157634.900 & 0.000 \\
\hline Finance & 1146 & 0.000 & -0.005 & 25.861 & -17.409 & 1.464 & 2.523 & 132.551 & 802629.700 & 0.000 \\
\hline Insurance & 1146 & 0.001 & -0.047 & 9.817 & -8.251 & 1.103 & 0.474 & 18.974 & 12227.530 & 0.000 \\
\hline Hydropower & 695 & 0.015 & -0.041 & 10.668 & -8.879 & 2.262 & 0.408 & 5.724 & 234.214 & 0.000 \\
\hline Hotel & 1146 & 0.000 & -0.071 & 32.097 & -7.636 & 1.109 & 20.908 & 617.305 & 18102938.000 & 0.000 \\
\hline Trading & 1146 & 0.000 & -0.072 & 43.820 & -9.039 & 1.608 & 17.706 & 485.556 & 11178942.000 & 0.000 \\
\hline Manufacturing & 1146 & 0.000 & -0.038 & 12.617 & -22.783 & 0.993 & -8.516 & 286.781 & 3859248.000 & 0.000 \\
\hline Other & 1146 & 0.000 & -0.038 & 40.029 & -53.672 & 2.713 & -2.779 & 189.400 & 1660546.000 & 0.000 \\
\hline
\end{tabular}




\section{Table 4: Descriptive statistics of weekly stock returns (Corrected data)}

The table represents descriptive statistics and the tests of normality for weekly stock returns on the corrected data of Nepal Stock Exchange (NEPSE). Descriptive statistics include mean, median maximum, minimum and standard deviation. Normality tests statistics include Skewness, Kurtosis and Jarque-Bera tests. Estimates are given for overall market returns series as well as for nine other sectors returns series for full sample study period from July 17, 2000 to July 15, 2010 and the two sub-periods.

\begin{tabular}{|c|c|c|c|c|c|c|c|c|c|c|}
\hline Indices & Observations & Mean & Median & Maximum & Minimum & Std. Dev. & Skewness & Kurtosis & Jarque-Bera & Probability \\
\hline \multicolumn{11}{|c|}{ Panel A: 2000 July 17 - 2010 July 15} \\
\hline Overall & 511 & 0.010 & -0.070 & 13.870 & -10.901 & 3.345 & 0.274 & 4.798 & 75.254 & 0.000 \\
\hline Commercial Banking & 511 & 0.010 & 0.025 & 21.912 & -17.012 & 4.339 & 0.097 & 5.857 & 174.630 & 0.000 \\
\hline Development Banking & 433 & 0.024 & -0.184 & 26.039 & -40.643 & 5.322 & -0.553 & 16.771 & 3443.458 & 0.000 \\
\hline Finance & 511 & -0.003 & -0.033 & 13.911 & -23.416 & 2.921 & -0.741 & 17.374 & 4445.956 & 0.000 \\
\hline Insurance & 511 & -0.003 & -0.089 & 14.642 & -16.820 & 2.953 & -0.305 & 11.347 & 1491.338 & 0.000 \\
\hline Hydropower & 152 & 0.124 & -0.277 & 20.612 & -13.854 & 4.990 & 0.881 & 5.587 & 62.024 & 0.000 \\
\hline Hotel & 511 & -0.006 & -0.036 & 36.305 & -14.126 & 2.531 & 5.180 & 88.925 & 159485.400 & 0.000 \\
\hline Trading & 511 & -0.0002 & -0.161 & 42.869 & -16.124 & 2.819 & 6.701 & 110.566 & 250179.100 & 0.000 \\
\hline Manufacturing & 511 & 0.005 & -0.046 & 16.689 & -19.654 & 1.742 & -1.724 & 57.934 & 64505.460 & 0.000 \\
\hline Other & 511 & 0.004 & -0.105 & 107.385 & -22.677 & 7.300 & 8.299 & 111.258 & 255400.200 & 0.000 \\
\hline \multicolumn{11}{|c|}{ Panel B: 2000 July 17 - 2005 July 16} \\
\hline Overall & 257 & 0.006 & -0.074 & 13.288 & -10.084 & 2.910 & 0.481 & 6.534 & 143.633 & 0.000 \\
\hline Commercial Banking & 257 & 0.003 & 0.005 & 21.147 & -16.126 & 4.212 & 0.288 & 7.395 & 210.353 & 0.000 \\
\hline Development Banking & 179 & 0.038 & 0.115 & 5.861 & -24.930 & 2.429 & -5.986 & 63.828 & 28665.040 & 0.000 \\
\hline Finance & 257 & -0.002 & -0.039 & 8.286 & -5.555 & 1.270 & 0.684 & 11.636 & 818.611 & 0.000 \\
\hline Insurance & 257 & 0.015 & -0.042 & 10.484 & -9.546 & 1.924 & 0.196 & 11.503 & 775.823 & 0.000 \\
\hline Hydropower & N.A. & & & & & & & & & \\
\hline Hotel & 257 & 0.003 & 0.249 & 8.267 & -11.557 & 2.141 & -0.987 & 11.368 & 791.504 & 0.000 \\
\hline Trading & 257 & 0.0004 & 0.002 & 7.593 & -8.980 & 1.639 & -0.840 & 13.485 & 1207.453 & 0.000 \\
\hline Manufacturing & 257 & 0.008 & 0.077 & 14.832 & -18.596 & 2.124 & -1.829 & 39.325 & 14272.670 & 0.000 \\
\hline Other & 257 & 0.003 & -0.042 & 118.940 & -22.980 & 9.451 & 8.774 & 105.942 & 116773.700 & 0.000 \\
\hline \multicolumn{11}{|c|}{ Panel C: 2005 July $17-2010$ July 15} \\
\hline Overall & 254 & 0.015 & -0.001 & 11.747 & -11.246 & 3.726 & 0.106 & 3.761 & 6.601 & 0.037 \\
\hline Commercial Banking & 254 & 0.017 & 0.081 & 14.075 & -16.467 & 4.466 & -0.096 & 4.287 & 17.916 & 0.000 \\
\hline Development Banking & 254 & 0.001 & -0.720 & 26.244 & -42.172 & 6.679 & -0.130 & 10.813 & 646.746 & 0.000 \\
\hline Finance & 254 & -0.0004 & 0.080 & 16.405 & -27.382 & 4.125 & -0.854 & 14.067 & 1327.114 & 0.000 \\
\hline Insurance & 254 & -0.045 & -0.116 & 17.635 & -19.759 & 3.955 & -0.248 & 8.809 & 359.785 & 0.000 \\
\hline Hydropower & 152 & 0.124 & -0.277 & 20.612 & -13.854 & 4.990 & 0.881 & 5.587 & 62.024 & 0.000 \\
\hline Hotel & 254 & -0.019 & -0.337 & 38.888 & -8.376 & 2.829 & 10.190 & 142.744 & 211072.400 & 0.000 \\
\hline Trading & 254 & -0.001 & -0.327 & 43.749 & -16.595 & 3.636 & 6.793 & 86.533 & 75802.240 & 0.000 \\
\hline Manufacturing & 254 & -0.0001 & -0.172 & 7.070 & -6.411 & 1.339 & 0.823 & 13.341 & 1160.461 & 0.000 \\
\hline Other & 254 & 0.004 & -0.169 & 52.049 & -18.017 & 4.592 & 5.648 & 67.809 & 45802.540 & 0.000 \\
\hline
\end{tabular}


Table 5: Serial correlation in daily stock returns (Observed data)

The table reports test results of serial correlation coefficient, i.e., the relationship between returns in the current period and those in the previous period, for daily market returns series on the observed data of Nepal Stock Exchange (NEPSE). Correlation coefficient and p-value are given for overall market returns series as well as for nine other sectors returns series for full sample study period from July 17, 2000 to July 15, 2010 and the two sub-periods.

\begin{tabular}{|c|c|c|c|c|c|c|}
\hline \multirow[t]{2}{*}{ Indices } & \multicolumn{2}{|c|}{$\begin{array}{c}\text { Overall Period } \\
\text { (2000 July } 17-2010 \text { July } 15) \\
\end{array}$} & \multicolumn{2}{|c|}{$\begin{array}{c}\text { First Half Period } \\
\text { (2000 July } 17-2005 \text { July 16) } \\
\end{array}$} & \multicolumn{2}{|c|}{$\begin{array}{c}\text { Second Half Period } \\
(2005 \text { July } 17-2010 \text { July } 15) \\
\end{array}$} \\
\hline & Coefficient & $p$-value & Coefficient & $p$-value & Coefficient & $p$-value \\
\hline Overall & -0.079 & 0.000 & -0.268 & 0.000 & 0.332 & 0.000 \\
\hline Commercial Banking & 0.012 & 0.556 & -0.164 & 0.000 & 0.281 & 0.000 \\
\hline Development Banking & -0.184 & 0.000 & -0.421 & 0.000 & 0.244 & 0.000 \\
\hline Finance & -0.403 & 0.000 & -0.474 & 0.000 & -0.315 & 0.000 \\
\hline Insurance & -0.381 & 0.000 & -0.460 & 0.000 & 0.215 & 0.000 \\
\hline Hydropower & 0.295 & 0.000 & N.A. & - & 0.295 & 0.000 \\
\hline Hotel & 0.005 & 0.805 & -0.072 & 0.013 & 0.082 & 0.006 \\
\hline Trading & 0.032 & 0.118 & -0.099 & 0.001 & 0.070 & 0.017 \\
\hline Manufacturing & -0.311 & 0.000 & -0.227 & 0.000 & -0.444 & 0.000 \\
\hline Other & -0.085 & 0.000 & 0.057 & 0.048 & -0.253 & 0.000 \\
\hline
\end{tabular}

\section{Table 6: Serial correlation in weekly stock returns (Observed data)}

The table reports test results of serial correlation coefficient, i.e., the relationship between returns in the current period and those in the previous periods, for weekly market returns series on the observed data of Nepal Stock Exchange (NEPSE). Correlation coefficient and p-value are given for overall market returns series as well as for nine other sectors returns series for full sample study period from July 17, 2000 to July 15, 2010 and the two sub-periods.

\begin{tabular}{|c|c|c|c|c|c|c|}
\hline \multirow[t]{2}{*}{ Indices } & \multicolumn{2}{|c|}{$\begin{array}{c}\text { Overall Period } \\
\text { (2000 July } 17-2010 \text { July 15) } \\
\end{array}$} & \multicolumn{2}{|c|}{$\begin{array}{c}\text { First Half Period } \\
\text { (2000 July } 17-2005 \text { July 16) }\end{array}$} & \multicolumn{2}{|c|}{$\begin{array}{c}\text { Second Half Period } \\
(2005 \text { July } 17-2010 \text { July } 15) \\
\end{array}$} \\
\hline & Coefficient & $p$-value & Coefficient & $p$-value & Coefficient & $p$-value \\
\hline Overall & 0.102 & 0.021 & 0.068 & 0.269 & 0.121 & 0.053 \\
\hline Commercial Banking & 0.023 & 0.595 & -0.004 & 0.955 & 0.048 & 0.439 \\
\hline Development Banking & 0.263 & 0.000 & 0.063 & 0.391 & 0.291 & 0.000 \\
\hline Finance & 0.232 & 0.000 & -0.180 & 0.004 & 0.343 & 0.000 \\
\hline Insurance & 0.311 & 0.000 & 0.056 & 0.365 & 0.453 & 0.000 \\
\hline Hydropower & 0.115 & 0.150 & N.A. & & 0.115 & 0.150 \\
\hline Hotel & 0.015 & 0.727 & -0.105 & 0.091 & 0.093 & 0.134 \\
\hline Trading & 0.015 & 0.728 & -0.090 & 0.146 & 0.039 & 0.532 \\
\hline Manufacturing & -0.266 & 0.000 & -0.329 & 0.000 & 0.095 & 0.127 \\
\hline Other & 0.017 & 0.694 & 0.112 & 0.070 & -0.199 & 0.001 \\
\hline
\end{tabular}




\section{Table 7: Serial correlation in daily stock returns (Corrected data)}

The table reports test results of serial correlation coefficient, i.e., the relationship between returns in the current period and those in the previous periods, for daily market returns series on the corrected data of Nepal Stock Exchange (NEPSE). Correlation coefficient and p-value are given for overall market returns series as well as for nine other sectors returns series for full sample study period from July 17, 2000 to July 15, 2010 and the two sub-periods.

\begin{tabular}{|c|c|c|c|c|c|c|}
\hline \multirow[t]{2}{*}{ Indices } & \multicolumn{2}{|c|}{$\begin{array}{c}\text { Overall Period } \\
\text { (2000 July } 17 \text { - 2010 July 15) } \\
\end{array}$} & \multicolumn{2}{|c|}{$\begin{array}{c}\text { First Half Period } \\
\text { (2000 July } 17-2005 \text { July 16) } \\
\end{array}$} & \multicolumn{2}{|c|}{$\begin{array}{c}\text { Second Half Period } \\
\text { (2005 July } 17-2010 \text { July } 15) \\
\end{array}$} \\
\hline & Coefficient & $p$-value & Coefficient & $p$-value & Coefficient & $p$-value \\
\hline Overall & 0.001 & 0.970 & -0.018 & 0.540 & 0.031 & 0.292 \\
\hline Commercial Banking & -0.000 & 0.988 & 0.002 & 0.939 & 0.021 & 0.472 \\
\hline Development Banking & -0.001 & 0.977 & -0.094 & 0.007 & -0.010 & 0.742 \\
\hline Finance & -0.072 & 0.001 & -0.135 & 0.000 & -0.026 & 0.371 \\
\hline Insurance & 0.006 & 0.787 & -0.117 & 0.000 & -0.024 & 0.409 \\
\hline Hydropower & -0.001 & 0.987 & N.A. & & -0.001 & 0.987 \\
\hline Hotel & -0.000 & 0.994 & -0.003 & 0.912 & -0.008 & 0.785 \\
\hline Trading & -0.001 & 0.962 & 0.005 & 0.876 & -0.001 & 0.965 \\
\hline Manufacturing & -0.061 & 0.003 & -0.046 & 0.113 & -0.102 & 0.001 \\
\hline Other & 0.002 & 0.918 & -0.002 & 0.935 & -0.012 & 0.673 \\
\hline
\end{tabular}

\section{Table 8: Serial correlation in weekly stock returns (Corrected data)}

The table reports test results of serial correlation coefficient, i.e., the relationship between returns in the current period and those in the previous periods, for weekly market returns series on the corrected data of Nepal Stock Exchange (NEPSE). Correlation coefficient and p-value are given for overall market returns series as well as nine for other sectors returns series for full sample study period from July 17, 2000 to July 15, 2010 and the two sub-periods.

\begin{tabular}{|c|c|c|c|c|c|c|}
\hline \multirow[t]{2}{*}{ Indices } & \multicolumn{2}{|c|}{$\begin{array}{c}\text { Overall Period } \\
\text { (2000 July } 17 \text { - 2010 July 15) }\end{array}$} & \multicolumn{2}{|c|}{$\begin{array}{c}\text { First Half Period } \\
\text { (2000 July } 17-2005 \text { July 16) }\end{array}$} & \multicolumn{2}{|c|}{$\begin{array}{c}\text { Second Half Period } \\
\text { (2005 July } 17-2010 \text { July } 15) \\
\end{array}$} \\
\hline & Coefficient & $p$-value & Coefficient & $p$-value & Coefficient & $p$-value \\
\hline Overall & -0.011 & 0.810 & -0.003 & 0.957 & -0.017 & 0.785 \\
\hline Commercial Banking & -0.001 & 0.975 & 0.000 & 0.999 & -0.005 & 0.935 \\
\hline Development Banking & 0.001 & 0.978 & 0.009 & 0.903 & 0.003 & 0.959 \\
\hline Finance & -0.046 & 0.297 & 0.019 & 0.765 & -0.058 & 0.354 \\
\hline Insurance & -0.016 & 0.715 & -0.008 & 0.895 & 0.043 & 0.486 \\
\hline Hydropower & -0.003 & 0.974 & N.A. & & -0.003 & 0.974 \\
\hline Hotel & 0.002 & 0.970 & -0.028 & 0.656 & 0.002 & 0.978 \\
\hline Trading & -0.002 & 0.969 & 0.006 & 0.921 & -0.004 & 0.944 \\
\hline Manufacturing & -0.022 & 0.615 & -0.045 & 0.467 & -0.002 & 0.980 \\
\hline Other & -0.001 & 0.990 & -0.003 & 0.961 & -0.005 & 0.939 \\
\hline
\end{tabular}




\section{Concluding remarks}

It is concluded that the indices suffered from the problem of infrequent (or thin) trading. The serial correlations were found in the majority of the indices in both daily and weekly returns series. On the contrary, after adjusted infrequent trading, i.e., corrected data on daily and weekly, as suggested by Miller et al. (1994), no serial correlation for the all indices was found. It provided the evidence that corrected return series reduces the autocorrelation. The result was consistent with Miller et al. (1994), who stressed that thin trading adjustment reduces the negative correlation among returns. Thus, the data should be improved from the problem of thin trading to make further studies in the Nepalese stock market. After corrected data employing model of Miller et al. (1994), the Nepalese stock market was efficient in weak form and random walk.

\section{REFERENCES}

Abeysekera, S. P. (2001). Efficient markets hypothesis and the emerging capital market in Sri Lanka: Evidence from the Colombo Stock Exchange - A note. Journal of Business Finance \& Accounting, $28(1$ and 2), 249-261.

Agrawal, D., \& Pathak, Y. (2007). Efficient market hypothesis: A study of S\&P CNX Nifty. Working Paper. Retrieved from http://www.ssrn.com

Ahmad, K. M., Ashraf, S., \& Ahmed, S. (January 7, 2006). Testing weak form efficiency for Indian stock markets. Economic and Political Weekly, 49-56.

Alam, I. M., Hasan, T., \& Kadapakham, P. (1999). An Application of variance-ratio test to five Asian stock markets. Review of Pacific Basin Financial Markets and Polices, 2, 301-315.

Belgaumi, M. S. (1995). Efficiency of the Indian stock market: An empirical study. Vikalpa, 20(2), 43-52.

Bhatta, G. P. (2008). Stock market efficiency in Nepal. (Doctoral dissertation, Tribhuvan University, 2008)

Bhatta, G. P. (2010). Does Nepalese stock market follow random walk? SEBON Journal, 4, 18-58.

Chaudhuri, S. K. (1991). Short-run share price behaviour: New evidence on weak form of market efficiency. Vikalpa, 16(4), 17-21. 
Cheung, K., \& Coutts, J. A. (2001). A note on weak form market efficiency in securities prices: Evidence from the Hong Kong Stock Exchange. Applied Economics Letters, 8, 407-410.

Chiang, K., Frankfurter, G. M., Kosedag, A., \& Wood, B. G. (2006). The perception of dividends by professional investors. Managerial Finance, 32(1), 60-81.

Dangol, J. (2010a). Efficient market hypothesis and the emerging capital market in Nepal. In Efficient Market Hypothesis: Few Empirical Evidences from Nepalese Stock Market, Kathmandu: Quest Publication

Dangol, J. (2010b). Testing random-walk behaviour in Nepalese stock market. PYC Nepal Journal of Management, 3(1), 26-34.

Dangol, J. (2011). Test of random-walk and stock market efficiency in Nepal and India. MIMT Journal of IT \& Management Research, 1(1), 73-85.

Dangol, J. (2012). Stock market efficiency in Nepal. Zenith International Journal of Multidisciplinary Research, 2(5), 40-48.

Fama, E. F. (1970). Efficient capital markets: A review of theory and empirical work. The Journal of Finance, 25(2), 383-417.

Fama, E. F. (1991). Efficient capital markets: II. The Journal of Finance, 46(5), 1575-1617.

Fama, E. F. (1998). Market efficiency, long-term returns, and behavioral finance. Journal of Financial Economics, 49(3), 283-306.

Fama, E. F., \& French, K. R. (1988). Permanent and temporary components of stock prices. Journal of Political Economy, 96(2), 246-273.

Gupta, R., \& Basu, P. K. (2007). Weak form efficiency in Indian stock markets. International Business and Economics Research Journal, 6(3), 57-64.

Islam, A., \& Khaled, M. (2005). Tests of weak-form efficiency of the Dhaka Stock Exchange. Journal of Business Finance \& Accounting, 32(7 \& 8), 1613-1624.

Jarrett, J. E., \& Kyper, E. (2005). Daily variation, capital market efficiency and predicting stock market returns. Management Research News, 28(8), 34-47.

Jegadeesh, N. (1990). Evidence of predictable behavior of security returns. The Journal of Finance, 45(3), 881-898.

Lee, C. F., Chen, G-M, \& Rui, O. M. (2001). Stock returns and volatility on China's stock markets. The Journal of Financial Research, 24(4), 523-543. 
Lo, A. W., \& MacKinlay, A. C. (1988). Stock market prices do not follow random walks: Evidence from a simple specification test. The Review of Financial Studies, 1(1), 41-66.

Miller, M. H., Muthuswamy, J., \& Whaley, R. E. (1994). Mean reversion of Standard \& Poor's 500 index basis changes: Arbitrage-induced or statistical illusion? The Journal of Finance, 49(2), 479-513.

Mishra, P. K. (2009). Indian capital market - Revisiting market efficiency. Indian Journal of Capital Markets, 2(5), 30-34. Retrieved from www.ssrn.com

Mishra, P. K., Das, K. B., \& Pradhan, B. B. (2009). Empirical evidence on Indian stock market efficiency in context of the global financial crisis. Global Journal of Finance and Management, 1(2), 149-157.

Mishra, P. K., \& Pradhan, B. B. (2009). Capital market efficiency and financial innovation A perspective analysis. The Research Network, 4(1), 1-4. Retrieved from www.ssrn.com

Mobarek, A., \& Keasey, K. (2002). Weak-form market efficiency of an emerging market: Evidence from Dhaka stock market of Bangladesh. Working Paper. Retrieved from http://www.ssrn.com

Narayan, P., \& Prasad, A. (2007). Mean reversion in stock prices: New evidence from Panel unit root tests for seventeen European countries. Economic Bulletin, 3(34), 1-6.

Pradhan, R. S., \& Upadhyay, B. D. (2006). The efficient market hypothesis and the behaviour of share prices in Nepal. In Research in Nepalese Finance, Kathmandu: Buddha Academics. Retrieved from www.ssrn.com

Rawashdeh, M., \& Squalli, J. (2006). A sectoral efficiency analysis of the Amman Stock Exchange. Applied Financial Economics Letters, 2, 407-411.

Shrestha, M. K. (2010). Stock market in Nepal: Cyclical pattern. Nepalese Economic Review, 2(3), 140-150.

Siddiqui, S., \& Gupta, P. K. (2009). Weak form of market efficiency- Evidences from selected NSE indices. Working Paper. New Delhi: Centre for Management Studies, Jamia Millia Islamia University. Retrieved from www.ssrn.com

Smith, G., Jefferies, K., \& Ryoo, H-J (2002). African stock markets: Multiple variance ratio tests of random walks. Applied Financial Economics, 12(7), 475-484.

Strong, N. (1992). Modelling abnormal returns: A review article. Journal Business Finance \& Accounting, 19(4), 533-553.

Summers, L. H. (1986). Does the stock market rationally reflect fundamental values?, Journal of Finance, 41(3), 591-601 
Uddin, M. G. S., \& Khoda, A. K. M. N. (2009). Testing random walk hypothesis for Dhaka Stock Exchange: An empirical examination. International Research Journal of Finance and Economics, 33, 64-76.

Urrutia, J. L. (1995). Tests of random walk and market efficiency for Latin American emerging markets. Journal of Financial Research, 18(3), 299-309.

Woolridge, J. R. (1983). Dividend changes and security prices. The Journal of Finance, 38(5), 1607-1615.

Worthington, A. C., \& Higgs, H. (2009). Efficiency in the Australian stock market, 18752006: A note on extreme long-run random walk behaviour. Applied Economics Letters, 16, 301-306. 